\title{
On Post-Crisis Banks' Fair Value Measurement Disclosure
}

\author{
Amira Annabi, PhD \\ Department of Economics and Finance, Manhattan College, United States of America \\ amira.annabi@manhattan.edu \\ Alicja K. Reuben, PhD \\ New York University Abu Dhabi, Saadiyat Island, United Arab Emirates \\ alicja.reuben@nyu.edu
}

\begin{abstract}
In this paper, we study the interplay between the popularity of valuation techniques adopted by the banks, the banks' perception of the broader risk environment, and their relative performance. In examining this relationship, we rely on the performativity theory as it applies to the fields of accounting and economic sociology. Our data consists in newly disclosed accounting information collected from banks'10-K and 20-F reports from 2012 to 2015 . We use four key ingredients in our model: (1) the banks' return on equity as a proxy for performance; (2) the range of unobservable inputs as a proxy for the banks' risk assessment; (3) the intensity of use of valuation techniques, as a proxy for the popularity of these techniques; (4) valuation technique as market devices in the performative process. The regression results suggest that that the intensity of use of valuation techniques mediates the performative process between valuation techniques and banks' performance.
\end{abstract}

Keywords: accounting disclosure, economic sociology, theory of performativity, valuation techniques, investment banking, great recession, unobservable inputs, ROE, risk assessment. JEL Codes: C21, C22, D21, G01. G24, K23, Z13, M41, M48

\section{Introduction}

The 2008 global financial crisis and the subsequent near-collapse of the banking system prompted regulatory bodies to demand more transparency from banks with regards to the pricing of financial instruments, particularly derivatives. In March 2008, the U.S. Security Exchange Commission (SEC) recommended an amendment to the fair value disclosure requirements that make it mandatory for publicly listed banks to disclose information that is more specific. A few years later, in April 2011, the Financial Accounting Standards Board (FASB) issued an Accounting Standards Update titled "Fair value Measurement", also known as ASU 2011-04 Topic 820 (FASB, 2011). This amendment was created to achieve common fair value measurement and disclosure requirements across the U.S. Generally Accepted Accounting Principles (GAAP) and the International Financial Reporting Standards (IFRS). The FASB was extremely specific with the purpose of the update, emphasizing that its primary goal was to explain how fair value should be measured. ${ }^{1}$ The update did not require additional fair value measurements, nor did it establish standards for valuation practices. Rather, it required public companies, and more specifically banks, to disclose both quantitative and qualitative information regarding the valuation techniques used to price financial instruments (FASB, 2011). Although it is well established that for public firms, new accounting

${ }^{1}$ More details about the definition of the concept of fair value are provided in (Majercakova and Skoda, 2015) and (Palea, 2014)

The current issue and full text archive of this journal is available at www.jraspublications.org/index.php/JRAS/issue/archive

Journal of Research in Administrative Sciences (JRAS)

IX(I), 1-11, ISSN: 2664-2433 disclosure requirements provides useful information to investors and reduces uncertainty regarding future's earnings ( Ayres, et al., 2017; Barron, et al., 2016), more research has to be done to establish this correlation for financial firms, and banks in particular (Ayres, et al., 2017).

A recent trend in the literature highlights the recognition by regulators of the association between fair value measurements of assets and liabilities, and banks' stability (e.g. Landsman, 2007; Beatty and Liao, 2014; Bushman, 2014; Magnan, et al., 2015). The argument is that the use of fair value measurement helps to address information asymmetry, thus potentially reducing agency problems between managers and shareholders on one hand, and banks and regulators on the other hand. Some researchers also believe that the fair value measurement is not just the answer to the financial crisis, but also one of its causes (e.g. Beatty and Liao, 2014; Majercakova and Skoda, 2015).

For investment banks and other financial institutions that actively engage in financial market making activities, the 2011 accounting update was indeed of paramount importance. With this new requirement, the valuation of investment banks' assets and liabilities essentially became subject to greater transparency and scrutiny, at least for a few years. Indeed, the FASB reversed course recently by relaxing some of the requirements introduced in 2011. In January 
2016, it issued another Accounting Standards Update 2016-01, titled "Financial Instruments-Overall: Recognition and Measurement of Financial Assets and Financial Liabilities" (FASB, 2016). This update eliminates the requirement to disclose valuation methods and key assumptions used to estimate fair values. Despite the 2016 relaxation of the disclosure requirements, annual financial statement data available from 2012 to 2015 do contain valuable quantitative and qualitative information with respect to investment banks' valuation techniques. This includes not only the type of valuation techniques employed by banks, the fair values of different financial instruments, but also the various unobservable inputs. ${ }^{2}$ The banks were also required to disclose information on the statistical distribution of these inputs, such as the minimum, maximum, average and median values (this dataset was first collected by Annabi and Reuben, 2017).

With this backdrop in mind, our primary goal in this paper is to analyse the unique accounting information available in the annual financial statements disclosed between 2012 and 2015, as well as the interplay between the popularity of valuation techniques among the banks, the banks' perception of the broader risk environment, and their relative performance. In examining this interplay, we rely on the performativity theory as it applies to the field of economic sociology (Callon, 2007; MacKenzie and Millo, 2003; Callon and Muniesa, 2005; Callon et al., 2007). In this paper, we argue that the process through which banks price financial instruments using valuation techniques is performative. In order to display this performative process in our model, we depict a feedback loop (see figure 1).

Figure 1: Performative Process for Valuation Techniques

First, valuation techniques are inanimate objects, written and created for an unexercised purpose. They can be therefore qualified as market devices, which marks the beginning of their existence. As banks begin to disclose their choice of valuation techniques, i.e.:

FIGURE 1

Performative Process for Valuation Techniques

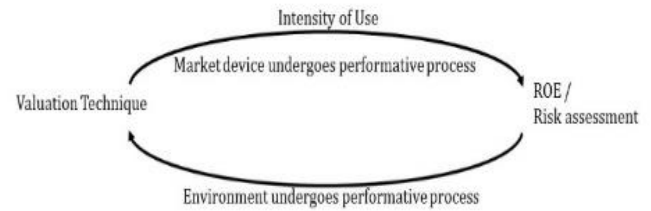

they interact with the market devices and allow them to enact the environment, the performative process starts shaping up. Three key variables drive this performative process: 1 . the popularity of the valuation techniques which determines their ability to attract a critical mass of participants; 2 . the banks assessment of the broader risk environment; and 3. the banks' performance relative to their peers.

\footnotetext{
${ }^{2}$ In their Dec 2013 10-K report, Morgan Stanley defines the unobservable inputs as “... inputs that reflect the Company's assumptions about the assumptions other market participants would use in pricing the asset or liability that were developed based on the best information available in the circumstances." (Morgan Stanley, 2013, p. 146).
}

To test the performative process depicted in Figure 1, we proxy the popularity of the valuation techniques using the intensity of use of valuation techniques, a frequency measure of how often banks use a certain valuation technique for a certain traded asset or liability. Put differently, the intensity of use construct measures the popularity of each individual valuation technique. While a novel construct, intensity has a foundation in applied accounting literature. For example, Scott and Orlikowski (2012) utilize TripAdvisor's "Popularity Index" as a measure that correlates with the accountability of traveller's experiences. This Index, like our intensity of use construct, assesses the degree to which a market device (in their case a travel destination and in our case a valuation technique) has a relationship with a performance outcome.

As a measure of the banks' perception of the broader risk environment, we use a risk index that ranks the banks according to their risk perception or assessment (Annabi and Reuben, 2017). This risk index is inversely proportional to the range of unobservable inputs: the wider the range, the higher the bank's risk assessment, and vice versa. Our basic prior is that the choice of a given valuation technique and the corresponding inputs is partly informed by the bank's perception of the riskiness of its operating environment. For example, a wide range of unobservable inputs disclosed for a given technique likely reflects more uncertainty over the future value of the priced instruments, the broader operating environment and therefore the bank's own profitability outlook. Conversely, a tight range likely indicates greater confidence over the forward outlook. ${ }^{3}$ Finally, we use the Return on Equity (ROE) as a measure of investment banks' performance. As an additional robustness check, we also use the Return on Assets (ROA) as an alternative measure of banks' performance. A recent trend in the accounting literature discusses the performativity of performance measures, as well as manager's attitudes toward performance measure (Andon et al., 2007; Dambrin and Robson, 2011; Bürkland et al., 2010; Jordan and Messner, 2012). In our paper, we conjecture that managers and shareholders agree with the banks' publicly disclosed shareholder policies, and consider ROE as a measure of banks' performance.

We empirically investigate the interplay between the popularity of the valuation techniques, the banks assessment of the broader risk environment, and the banks' performance relative to their peers. To do so, we estimate regression models with fixed effects on unobservable inputs. Our findings are twofold. First, the banks' performance exhibits an inverse relationship with the intensity of use. Put differently, the higher the intensity of use or the more popular the valuation technique is, the lower the banks' relative performance. This inverse relationship suggests that techniques that are more popular lead to more competition between banks, and thus narrows the profitability gap among them. Second, the higher the risk assessment, i.e.: the higher is the perception with regard to the riskiness of the operating environment; the lower is the intensity of use. In other words, a wider range of unobservable inputs is typically associated with a less frequently used technique, and vice versa. Taken together, these results suggest that the intensity of use mediates the performative process between valuation techniques and ROE.

Our paper extends the original dataset of Annabi and Reuben (2017) from 2 to 4 years. Moreover, we collect additional data on the intensity of use of the various valuation techniques. While Annabi and Reuben (2017) examine the determinants of the choice of the valuation techniques in a game theory setting, we adopt in this paper a performativity theory framework to explore the relationship between the popularity of valuation techniques, the banks'

${ }^{3}$ The risk-taking literature generally associates the construct of risk with the extent to which a decision's expected outcomes are uncertain, decision goals are difficult to achieve, or the potential outcome set includes some extreme consequences ( Gray and Cannelle, 1997; Sitkin and Pablo, 1992; Weber and Milliman, 1997; Wiseman and Gomez-Mejia, 1998). Our risk index captures these features. 
performance and risk assessment. More specifically, we use regression analysis to investigate these associations. Our paper proposes a novel framework where valuation techniques are considered market devices that, by creating its environment, act as an engine to also transform it. We therefore contribute to the growing literature on the application of the theory of performativity to the fields of finance and accounting.

The rest of the paper proceeds as follows. In section 2, we discuss our conjecture that valuation techniques are market devices. In section 3, we present the annual financial statement data covering the period from 2012 to 2015 . Our sample includes the majority of US primary dealers. In section 4, we discuss the intensity of use of valuation techniques, the risk assessment index, and the ROE and ROA ratios. In section 5, we discuss the regression models and the key results. Section 6 provides concluding remarks.

\section{Are Valuation Techniques Market Devices?}

In our paper, we argue that valuation techniques are not only methods selected by investment banks to optimally price financial instruments in order to maximize profit, but also market devices. Our approach is novel, and draws from the theory of performativity as it applies to the fields of accounting as well as economic sociology.

The concept of performativity was first introduced in the field of linguistics by (Austin, 1962). In his seminal book, How to Do Things with Words, Austin (1962) discusses the concept of "performative utterance" and advances that "The name is derived, of course, from 'perform', the usual verb with the noun 'action': it indicates that the issuing of the utterance is the performing of an action -it is not normally thought of as just saying something". Adopted by economic sociology, performativity is the notion that economic theory is not just a mere approximate description of the real world, it very often shapes it or "performs" it (Mackenzie and Millo, 2003). In a recent paper attempting to build a bridge between the theory of performativity and the field of accounting, (Revellino and Mouritsen, 2015) investigates how calculative practices, such as accounting, act as engines to help changing the world rather than just describing it. They also argue that the performative nature of accounting leads to influence managers', firms' and institutions practices (Revellino and Mouritsen, 2015, p.33). Put another way, a pricing formula or valuation technique can be thought of as a device that stimulates the genesis and the development of a market or an economic environment. In finance, the market device reconfigures or enacts its own environment, i.e.: the market. A stock ticker is another example of market device. In a detailed analysis of the agential features of financial technologies, Preda (2006) explores the idea that the ticker is a technological market device that performs what trading, and traders, constitute in financial markets.

To better explain our argument that valuation techniques are market devices, we draw a parallel with the famous Black-Scholes-Merton (hereafter BSM) formula (Black and Scholes, 1973). The formula gained a lot traction as the standard tool for pricing financial derivatives, especially as practitioners relaxed many of its restrictive assumptions such as the absence of dividends and the use of a constant volatility parameter, which lead to the development and expansion of the option's market. Therefore, the BSM model, i.e.: the device, performed financial markets, i.e.: the environment (Mackenzie and Millo, 2003). More particularly, the performativity cycle allowed the BSM model to create the "phenomenon "of an asset with a known value (or at least so it was assumed) and subsequently enact the environment, i.e.: derivative markets, in which it is used. The performativity theory assumes that market devices engage their environment by creating individual reproduction of themselves (Callon and Muniesa, 2005). More recently, Abrahamson et al. (2016) defined market devices as business techniques, or linguistic prescriptions created to improve the operations of business organizations. The way in which the business techniques enact the business world make them more useful in that environment.
In our paper, we draw a parallel with the Mackenzie and Millo (2003), Abrahamson et al. (2016) and Revellino and Mouritsen (2015) papers, and argue that valuation techniques, as the BSM model, are market devices that enact their environment, and therefore potentially interact with banks performance and risk.

\section{Data Collection}

We collect data on the unobservable inputs as well as the valuation

\section{MORGAN STANLEI}

\section{NOTES TO CONSOLIDATED FINANCIALSTATEMENTS—-(Continued)}

The disclosures below also include qualitative information on the sensitivity of the fair value measurements to changes in the significant unobservable inputs.

\begin{tabular}{|c|c|c|c|c|c|c|c|}
\hline & 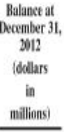 & $\begin{array}{c}\text { Valuation } \\
\text { Tectaingeiss }\end{array}$ & 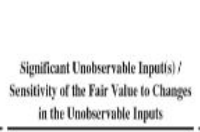 & & Ramge(1) & & $\begin{array}{l}\text { Weighted } \\
\text { Averige }\end{array}$ \\
\hline \multicolumn{8}{|l|}{$\begin{array}{l}\text { Fimancial instruments ownod: } \\
\text { Carponte and other debt: }\end{array}$} \\
\hline $\begin{array}{l}\text { Commercial mortgaye- baxked } \\
\text { secunities }\end{array}$ & 3232 & Comparable pricing & Comparable bond price /(A) & 4610 & 100 points & 76 & points \\
\hline Assel-baxked securitios & 109 & Discounted cash flow & Intemal rate of return $/(\mathrm{C})$ & & $21 \%$ & 21 & $\frac{5}{\pi}$ \\
\hline Corporale bands & 66(i) & Comparable pring & Comparable bond price/(A) & (1) 10 & 143 points & 24 & points \\
\hline \multirow[t]{2}{*}{ Collikeralized deth oblizations } & 1,951 & Compratible pring & Compurable bond price /(A) & 15 to & 88 points & 59 & poinls \\
\hline & & Correlation model & Crodili correlation/ (B) & 1510 & $45 \%$ & 4i) & 5 \\
\hline \multirow[t]{3}{*}{$\begin{array}{l}\text { Loass and lending } \\
\text { ommuiturats }\end{array}$} & 4,694 & Coppoate loan model & I Crodit spread /(C) & 17 101 & 1,004 bais points 2 & 281 & basis points \\
\hline & & Companable pring & Comparable bond price / $(A)$ & 80 to & 120 points & 104 & points \\
\hline & & Comparable pricing & Compurable lan prix $/(A)$ & 55 to & 100 poins & 88 & points \\
\hline \multirow[t]{3}{*}{ Carporate equities(2) } & 288 & Net asset value & Discount to net asset value /(C) & (1) to & $37 \%$ & 8 & s \\
\hline & & Compratable picing & Dissour to ampraible equity price /(C) & (1) 10 & 27 points & 14 & poinls \\
\hline & & Market spprouch & 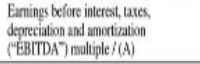 & & 6 times & 6 & tines \\
\hline \multirow[t]{8}{*}{ 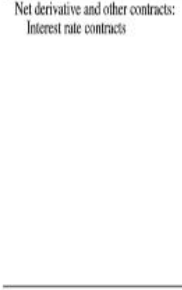 } & (82) & Option model & $\begin{array}{l}\text { Inseress rate volatility concentration } \\
\text { liquidity mulliple /(CY)(D) }\end{array}$ & 0 to & 8 times & & $\operatorname{Sex}(3)$ \\
\hline & & & Comparable bond price /(A)(D) & 510 & 98 points & & \\
\hline & & & 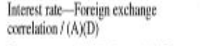 & 210 & $63 \%$ & & \\
\hline & & & 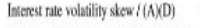 & 910 & $95 \%$ & & \\
\hline & & & Isterss talte quanto ourralation/(A)(D) & 5310 & $33 \%$ & & \\
\hline & & & Interess talte curve antlation /(A)(D) & $48 \mathrm{log}$ & $99 \%$ & & \\
\hline & & & Inflation udatilility $/(A, D)$ & 49 10 & $100 \%$ & & \\
\hline & & Discounted cash flow & 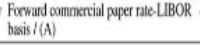 & 1810 & 95 basis points & & \\
\hline \multirow[t]{3}{*}{ Crodil coutracts } & 1,822 & Comparable prising & Cash synthelic busis /(C) & 2 to & 14 points & & $\operatorname{Sex}(4)$ \\
\hline & & & Comparatbe bond price /(C) & (1) 10 & 80 prinits & & \\
\hline & & Conrelkion model & Crodit conelation / (B) & 1410 & $94 \%$ & & \\
\hline \multirow[t]{5}{*}{ Foxeign exchange coulraxss(5) } & (359) & Option model & Compiardbe bond price /(A) $(D)$ & 510 & 98 povints & & $\operatorname{Sex}(6)$ \\
\hline & & & Ireness rate quanto ourclation $(A)(D)$ & .5310 & $33 \%$ & & \\
\hline & & & $\begin{array}{l}\text { Interess rale-Crodil spread } \\
\text { anclation/(A)D) }\end{array}$ & .5910 & $65 \%$ & & \\
\hline & & & 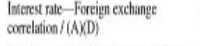 & 2 to & $62 \%$ & & \\
\hline & & & Interst rate volarility stew /(AKD) & 910 & $95 \%$ & & \\
\hline \multirow[t]{5}{*}{ Equity contrastis(5) } & $(1,144)$ & Option model & At be money volutility / $(C X Y D)$ & 7 to & $24 \%$ & & $\sec (7)$ \\
\hline & & & Volatility stew / $/ C X(D)$ & 210 & $0 \%$ & & \\
\hline & & & Equity-Equily correlitive /(C)(D) & 40 to & $96 \%$ & & \\
\hline & & & $\begin{array}{l}\text { Equity-Forign exchange curelatioa/ } \\
\text { (C)(D) }\end{array}$ & .7010 & $38 \%$ & & \\
\hline & & & $\begin{array}{l}\text { Equiry-Interst rale anclation/ } \\
\text { (C,D) }\end{array}$ & 1810 & $65 \%$ & & \\
\hline
\end{tabular}

techniques adopted by different banks. This data collection was made possible by the regulatory changes that required greater transparency and information disclosure. More specifically, the ASU 2011-04 requires companies to disclose quantitative information on unobservable inputs used in determining Level 3 measurements, a description of the valuation processes a company has in place for its Level 3 measurements and a description of the sensitivity of Level 3 fair-value measurements to changes in the unobservable inputs. Aside from the above three requirements, the ASU 2011-04 does not provide specific guidance on what quantitative information should be disclosed to meet the requirement described in the first item above. Instead, it includes an 
example of the type of information companies may disclose (FASB, 2011).

We examine $10-\mathrm{Ks}$ and 20 -Fs reports for the fiscal years spanning the 2012-2015 period. We first start by selecting the entire population of US primary dealers as of 2012 (21 dealers in total) and then retain dealers for which data on valuation techniques used to price the different assets and liabilities are available. ${ }^{4}$ Error! Reference source not found. is an illustration of how this newly disclosed information is displayed in the annual reports.
Table 1: Data Description

Figure 1: Morgan Stanley- Notes to Consolidated Financial

Statements

This figure shows that Morgan Stanley discloses at least one valuation technique per tradable asset, as well as at least one unobservable input per valuation technique. This trend is also observed across all the banks in our sample.

Error! Reference source not found. shows the eight different banks in our sample, as well as the different categories of financial instruments, as well as valuation techniques.

\begin{tabular}{llll} 
Investment Banks & Financial Instruments & Valuation Techniques & Unobservable Inputs \\
\hline Bank of America & Corporate debt & Comparable price model & Correlation \\
Citibank & Corporate equity & Corporate loan model & Price \\
Credit Suisse & Derivatives & Correlation model & Rate \\
Goldman Sachs & Structured product & Discounted cash flow & Severity \\
Jefferies & & Internal model & Spread \\
JP Morgan Chase & & Market approach & Volatility \\
Morgan Stanley & & Net asset value & Yield \\
Nomura Group & & Option model & \\
\hline
\end{tabular}

Moreover, we bucket the numerous collected unobservable inputs into the following seven distinct categories:

1. Correlation encompasses the following valuation techniques: commodity correlation, credit correlation, cross-commodity correlation, equity-equity correlation, equity-FX correlation, equity-interest rate correlation, interest rate curve correlation, interest rate-FX correlation and interest rate-interest rate correlation.

2. Price includes bond price, comparable equity price, comparable loan price, comparable price, price per barrel of oil and price per megawatt hour of power.

3. Rate covers recovery rate, capitalization rate, conditional default rate, cumulative loss rate, default rate, discount rate and prepayment rate.

4. Severity is an abbreviation for loss severity.

5. Spread comprises credit spread as well as spread per Million British Thermal Units (MMBTU) of natural gas.

6. Volatility covers at-the-money volatility, commodity volatility, equity volatility, FX volatility and inflation volatility.

7. Yield.

While regulators do require financial institutions to disclose the techniques used to value financial instruments, the data collected in our sample suggest that financial institutions are generally reluctant to provide detailed information. The pattern is consistent with the findings of Ernst and Young (2012), which document similarities and differences in the way public companies disclose their fair value measurement. To account for the variations in the degree of disclosure, we bucket the eight banks in our sample into three buckets according to the granularity of their disclosure.

- $\quad$ The first bucket includes Citibank and Goldman Sachs. These two banks discussed methods of fair-value measurement in their 2011 annual reports but disclosed a formal schedule with key unobservable inputs only in 2012. Taking Goldman Sachs as an example, the fair-value footnote of its 2011 10-K contains a schedule that presents the valuation techniques and the nature of significant inputs generally used to determine the fair values of each class of level 3 cash-instruments. The schedule also explains that for Goldman Sachs' cash instruments, the valuation techniques vary by instrument, but generally based on discounted cash flow techniques. However, in 2012, the schedule provides more detail, disclosing the range of significant unobservable inputs as of December 2012 and the value of the assets in each cash instrument category.

\footnotetext{
${ }^{4}$ The list is provided by the Federal Reserve Bank of New York through the following link https://www.newyorkfed.org/markets/primarydealers.html. This dataset extends the one built and used in (Annabi and Reuben,
}

- $\quad$ The second bucket includes Morgan Stanley and JP Morgan Chase, both of which do not disclose any valuation techniques in 2011. In the 2012 annual report, they disclose the full fairvalue schedule.

- The third bucket includes Bank of America, Credit Suisse, Jefferies and Nomura. These banks mention their valuation methods in their 2011 and 2012 annual reports but do not include a formal schedule.

We would also note that aside from the Discounted Cash Flows (hereafter DCF) method, financial institutions provide little information about cash flow forecasting techniques or the discountrate estimation methods. The $10-\mathrm{K}$ and $20-\mathrm{F}$ filings typically contain rather generic terms, such as "internally developed forecasts," "bespoke models," "observable proxy," "comparable," etc. Other models, such as comparable pricing, price-based, and the market approach, even more vaguely defined. In addition, the scenario analysis used to estimate value of an asset is usually defined as stress-testing for abnormal activity in financial markets.

\section{Drivers of the Performative Process}

We now turn to the construction of the three variables that drive the performative process: the intensity of use of valuation techniques, the banks' risk assessment, and the banks' performance as measured by ROE.

\section{Intensity of Use}

In order to measure the popularity of each valuation technique, we introduce a new frequency measure that we call Intensity of Use. The interpretation of this frequency measure is original to our paper, and we build it in order to assess whether banks have preference using certain valuation techniques. We define the intensity of use as the number of times a technique $a$ is used to price financial instruments to the number of times all the techniques are used in our sample. These calculations facilitated by the fact that companies report a variety of valuation techniques per traded debt or asset (see figure 2).

Table 1 summarizes the 8 valuation techniques used by banks in our sample, namely Comparable price model, Corporate loan model, Correlation model, Discounted cash flow, Internal model, Market approach, Net asset value and Option model. We denote the intensity of use of a valuation technique $a$ by $I_{a}$, where $a=$ $\{1, \ldots, 8\}$, and

$$
I_{a}=\sum_{b=1}^{4} \frac{n_{a, b}}{\sum_{a=1}^{8} n_{a, b}}
$$

where $n_{a, b}$ is number of times the valuation technique $a$ is used to price financial instrument $b(b=\{1, \ldots, 4\})$. The motivation

2017), which only covered the 2013 and 2014 fiscal years. Here, we add accounting information for two additional years: 2012 and 2015. 
behind defining the intensity of use measure is to assess to what extent a particular valuation technique used. Therefore, it describes the popularity of a technique among the banks in our sample. Table
2 shows the various levels of intensity attributable to the different classes of assets and valuation techniques.

Table 1: Average intensity of Use per Financial Instrument and Valuation Technique

\begin{tabular}{|c|c|c|c|c|c|c|c|c|}
\hline & $\mathrm{CP}$ & CLM & CM & DCF & IM & MA & NAV & $\mathrm{OM}$ \\
\hline Corporate Debt & $5.57 \%$ & $1.91 \%$ & $0.56 \%$ & $6.97 \%$ & $0.56 \%$ & $2.75 \%$ & $0.00 \%$ & $0.73 \%$ \\
\hline Corporate Equity & $2.30 \%$ & $0.00 \%$ & $0.28 \%$ & $2.14 \%$ & $0.17 \%$ & $3.26 \%$ & $0.56 \%$ & $0.11 \%$ \\
\hline Derivatives & $2.30 \%$ & $0.00 \%$ & $4.10 \%$ & $13.31 \%$ & $3.20 \%$ & $2.25 \%$ & $0.00 \%$ & $16.63 \%$ \\
\hline Structured Products & $6.29 \%$ & $0.22 \%$ & $0.51 \%$ & $19.66 \%$ & $0.51 \%$ & $1.97 \%$ & $0.00 \%$ & $1.18 \%$ \\
\hline $\begin{array}{l}\text { Intensity of use of valuation } \\
\text { technique }\end{array}$ & $16.46 \%$ & $2.13 \%$ & $5.45 \%$ & $42.08 \%$ & $4.44 \%$ & $10.23 \%$ & $0.56 \%$ & $18.65 \%$ \\
\hline
\end{tabular}

To calculate the intensity of use for each valuation technique $a$ per financial instrument $b$ reported in table 2, we use a modified version of equation

$$
I_{a, b}=\frac{n_{a, b}}{\sum_{a=1}^{8} n_{a, b}}
$$

Among the different valuation techniques used by the banks in our sample, the Discounted Cash Flow (DCF) method by far the most popular across the four categories of financial instruments. Indeed, DCF used to evaluate almost half the financial instruments traded by the eight banks in our sample. This might explained by the tractability of the valuation approach that consists in computing net present value or fair value of estimated, or forecasted, future cash flows and appropriate terminal value by discounting them with the appropriate discount rate. A similar definition of DCF model can found in financial literature (Williams, 1938; 1997 reprint; Gordon and Shapiro, 1956; Modigliani and Miller, 1958).

For the valuation of derivatives, we also find that banks tend to be extremely protective of their models. Other than a few instances mentioning the well-known BSM, for example, banks simply describe their over the counter derivative valuation process based on closed-form analytic formulas, simulations models, or a combination of the two. Another takeaway from Table 2 is that for the pricing approach for corporate equity, comparable price models seem to be the most widely used. We also notice that models that face a larger range of uncertainty and judgment, such as internal model, have a lower intensity of use across the four categories of assets and liabilities.

Table 3: Descriptive Statistics on Intensity of Use

\begin{tabular}{llllll}
\hline & Mean $(\%)$ & Median $(\%)$ & StDev $(\%)$ & Min $(\%)$ & Max $(\%)$ \\
\hline 2012 & 45.70 & 41.70 & 27.24 & 1.00 & 100.00 \\
2013 & 44.33 & 41.70 & 24.98 & 1.03 & 79.45 \\
2014 & 37.50 & 42.59 & 27.72 & 1.30 & 100.00 \\
2015 & 39.40 & 34.37 & 27.02 & 1.47 & 100.00 \\
\hline
\end{tabular}

Table 3 complements Table 2 and shows various summary statistics

Table 5: Descriptive Statistics for ROE, ROA, Size and GDP per Capita

\begin{tabular}{lcccccc}
\multicolumn{5}{c}{ Table 5: Descriptive Statistics for ROE, ROA, Size and GDP per Capita } \\
\hline \multirow{3}{*}{ ROE (\%) } & Year & Mean & Median & StDev & Min & Max \\
& 2012 & 5.33 & 3.99 & 4.28 & 0.11 & 11.48 \\
& 2013 & 7.34 & 6.39 & 2.50 & 4.75 & 11.39 \\
& 2014 & 6.54 & 5.95 & 3.34 & 2.19 & 11.70 \\
\multirow{3}{*}{ ROA (\%) } & 2015 & 6.57 & 8.43 & 5.82 & -6.27 & 11.28 \\
& 2012 & 0.37 & 0.19 & 0.36 & 0.01 & 0.92 \\
& 2013 & 0.58 & 0.58 & 0.20 & 0.25 & 0.86 \\
& 2014 & 0.51 & 0.42 & 0.29 & 0.20 & 0.96 \\
Size (\$US Billion) & 2015 & 0.62 & 0.75 & 0.44 & -0.31 & 0.99 \\
& 2012 & 3.07 & 0.15 & 5.15 & -0.18 & 29.97 \\
& 2013 & 2.28 & 1.13 & 3.27 & -1.59 & 15.21 \\
GDP per Capita (Current \$US) & 2014 & 6.05 & 0.66 & 16.83 & -2.36 & 88.15 \\
& 2015 & 2.17 & 0.94 & 2.98 & -2.03 & 24.81 \\
& 2012 & 56,189 & 50,027 & 18,460 & 41,538 & 83,164 \\
& 2013 & 55,077 & 47,597 & 20,451 & 40,454 & 84,659 \\
& 2014 & 56,230 & 50,505 & 20,842 & 38,069 & 85,815 \\
& 2015 & 53,900 & 50,068 & 20,133 & 34,474 & 80,990 \\
\hline
\end{tabular}


Table 2: Descriptive Statistics on Risk Assessment

\begin{tabular}{|c|c|c|c|c|c|c|c|c|c|c|c|c|c|c|c|c|c|c|c|c|}
\hline & \multicolumn{5}{|c|}{2012} & \multicolumn{5}{|c|}{2013} & \multicolumn{5}{|c|}{2014} & \multicolumn{5}{|c|}{2015} \\
\hline & Mean & StDev & Min & Max & $\mathrm{N}$ & Mean & StDev & Min & Max & $\mathrm{N}$ & Mean & StDev & Min & Max & $\mathrm{N}$ & Mean & StDev & Min & Max & $\mathrm{N}$ \\
\hline चे & 2.12 & 2.09 & .02 & 7.33 & 21 & 2.03 & 1.87 & 0 & 9 & 39 & 3.05 & 4.91 & 0.01 & 22.2 & 60 & 3.37 & 6.63 & 0 & 41.86 & 59 \\
\hline$\sum_{J}$ & 3.51 & - & 3.51 & 3.51 & 1 & 1.69 & .94 & .4 & 2.64 & 4 & 1.92 & .95 & 1.03 & 3.37 & 5 & 1.33 & .93 & 0 & 3.01 & 18 \\
\hline$\sum$ & 3.52 & 3.87 & 1.29 & 10.36 & 5 & 4.77 & 9.86 & .658 & 38.26 & 14 & 2.05 & 1.61 & .22 & 6.77 & 22 & 2.04 & 1.63 & 0 & 7.89 & 29 \\
\hline 岌 & 8.92 & 46.49 & 0 & 334 & 51 & 6.12 & 24.69 & 0 & 266.6 & 128 & 3.77 & 6.68 & 0 & 47 & 58 & 5.03 & 12.9 & 0 & 109 & 91 \\
\hline$\Sigma$ & - & - & - & - & - & 15.38 & 51.50 & .4 & 208.3 & 16 & - & - & - & - & & - & - & - & - & - \\
\hline $\mathbb{\Sigma}$ & 0 & - & 0 & 0 & 1 & 0.87 & 1.36 & 0 & 5.13 & 15 & 2.28 & 2.99 & 0 & 18.7 & 52 & 2.67 & 4.78 & 0 & 35.94 & 61 \\
\hline$\underset{z}{z}$ & 4.63 & - & 4.65 & 4.65 & 1 & 1.98 & - & 1.98 & 1.98 & 1 & - & - & - & - & - & - & - & - & - & - \\
\hline$\sum_{0}$ & 27.38 & 92.16 & .13 & 334 & 13 & 4.25 & 9.47 & 0 & 66.91 & 54 & 4.41 & 9.29 & .12 & 47 & 26 & 4.84 & 16.5 & 0 & 109 & 44 \\
\hline
\end{tabular}


Table 5 shows basic descriptive statistics on ROE and ROA. One can see that the average ROE in table 5 increased from 2012 to 2013, then slightly decreased in 2014 to remain almost constant in 2015 . Within our sample of banks, Goldman Sachs and JP Morgan were the best performers over the period 2012-2015. Relative to the precrisis period, banks ROE has substantially decreased due to tougher regulatory environment.

\section{Empirical Results}

\section{Characterizing the Performativity Cycle}

Our central argument is based on the premise that the intensity of use, or the popularity of techniques allows financial techniques to undergo a performativity cycle that correlates with not only the ROE of banks but also the risk assessment of traders. The foundation for this hypothesis is based on literature in applied accounting literature. Particularly, we derive this relationship from claims about accounts, as agents, affect the compromise between evaluative principles (Chenhall et al., 2013). In their paper, they describe the relationship between agents and compromise. More particularly, they consider agents as accounting principles, and like our valuation techniques, these principles act as market devices in the performative framework. The relationship between accounting principles and compromise is negative, namely these agents thwart cooperation among actors within the organization they study. This negative relationship serves as a basis for our propositions regarding the relationship between intensity of use and ROE. Market devices lead to negative financial performance in our case. The higher the level of intensity, the lower the level of ROE. In this sense, we find the Chenhall, Hall \& Smith (2013) evaluate a similar negative relationship.

We argue that the process through which banks price financial instruments using valuation techniques is performative. We define valuation techniques as, not only methods selected by investment banks to optimally price financial instruments in order to maximize profit, but also market devices.

The following two propositions define the interplay between the three key drivers of the performativity cycle: 1 . Intensity of use; 2 . the risk assessment index; and 3. ROE and ROA. What is important to note is that the intensity of use mediates the performative process between valuation techniques and ROE.

Proposition 1: The intensity of use of valuation techniques is inversely correlated with $R O E$

Proposition 2: The intensity of use of valuation techniques is inversely correlated with Risk Assessment

The first proposition states that the banks' performance exhibits an inverse relationship with the intensity of use, i.e.: the popularity of techniques. Put differently, the higher the intensity of use or the more popular the valuation technique is, the lower the banks' relative performance. The inverse relationship between intensity of use and ROE suggests that less profitable banks tend to use techniques that are more popular. The second proposition states that the higher the risk assessment, i.e.: the higher is the perception with regard to the riskiness of the operating environment; the lower is the intensity of use. In other words, a wider range of unobservable inputs is typically associated with a less frequently used technique, and vice versa. In terms of risk assessment, the intensity of use also has an impact of a particular sort on the "inherent unsettledness" that traders perceive valuation techniques to have (Andon et al., 2007).

\section{Regression Results}

To empirically investigate the associations between the banks' performance and the intensity of use on one hand, and the banks' risk assessment and the intensity of use on the other hand, we estimate the following regression models with fixed effects by company and by year:

$$
\begin{aligned}
& R O E_{i t}=\beta_{0}+\beta_{1} \text { Intensity }_{i t}+\beta_{2} \text { Size }_{i t}+\beta_{3} \text { U.S. } \text { Domicile }_{i t} \\
& \text { and } \\
& +\beta_{4} G D P_{t}+\mu_{i}+\lambda_{t}+\varepsilon_{i t} \\
& +\beta_{3} \text { U.S.Domicile }{ }_{i t}+\gamma_{i} \\
& +\mu_{i}+\lambda_{t}+\varepsilon_{i t}, \quad \text { (5) }
\end{aligned}
$$

where the ROE is based on twelve-month trailing figures (TTM), Risks Assessment refers to the risk assessment index as defined in equation (3), Intensity refers to the intensity of use as defined in equation (1), Size refers to the size of the balance sheet size in billions of dollars, Domicile is a dummy variable that equates 1 if the bank is domiciled in the US, and 0 otherwise, and GDP refers to the country of domicile's GDP per capita. In these equations $\mu_{i}$ represents fixed effects for company and $\lambda_{t}$ represents fixed effects for year.

The regression models shown in equations (4) and (5) essentially relate the bank's performance and risk assessment to the intensity of use of the valuation techniques, after controlling for the banks' balance sheet size and domicile, and GDP per capita.

More specifically, the regression shown in equation (4) relates each bank's ROE to our measure of the intensity of use of the various

\begin{tabular}{|c|c|c|c|c|}
\hline $\begin{array}{l}\text { Dependent } \\
\text { variable: ROE }\end{array}$ & (1) & (2) & (3) & (4) \\
\hline Intensity & $\begin{array}{l}-0.020 * * * \\
(0.003)\end{array}$ & $\begin{array}{l}-0.022 * * * \\
(0.004)\end{array}$ & $\begin{array}{l}-0.018 * * * \\
(0.004)\end{array}$ & $\begin{array}{l}-0.018 * * * \\
(0.005)\end{array}$ \\
\hline Size & & $\begin{array}{l}0.33^{* * * *} \\
(0.003)\end{array}$ & $\begin{array}{l}0.33^{* * * *} \\
(0.005)\end{array}$ & $\begin{array}{l}0.33 * * * \\
(0.002)\end{array}$ \\
\hline U.S. domicile & & & $\begin{array}{l}3.098 * * * \\
(0.652)\end{array}$ & $\begin{array}{l}1.042 * * * \\
(0.098)\end{array}$ \\
\hline GDP per Capita & & & & $\begin{array}{l}0.001 * \\
(0.001)\end{array}$ \\
\hline Constant & $\begin{array}{l}0.277 \\
(2.42)\end{array}$ & $\begin{array}{l}0.296 \\
(2.61)\end{array}$ & $\begin{array}{l}0.832 \\
(4.91)\end{array}$ & $\begin{array}{l}0.967 \\
(6.92)\end{array}$ \\
\hline No. Obs. & 31 & 31 & 31 & 31 \\
\hline Adj. R²(\%) & 26.03 & 31.35 & 36.43 & 58.76 \\
\hline
\end{tabular}
valuation techniques disclosed. We estimate the model using a standard maximum likelihood technique. Table 6 provides the coefficient estimates for various versions of the regression model shown in equation (4).

Table 6: Intensity of Use of Valuation Techniques and ROE

The key takeaway from table 6 is the negative cross-sectional correlation between the ROE and the intensity of use. More specifically, our results suggest that the banks strategic decision to adopt well-established, and popular, valuation techniques correlates with negative performance. This inverse relationship suggests that techniques that are more popular lead to more competition between banks, and thus narrows the profitability gap among the banks. We believe this result is an important contribution of our paper as banks strategic choices of valuation techniques have been available to study only recently due to the change in banks' disclosure regulation.

Table 6 also shows that the response of the ROE to the intensity of use decreases slightly when we control for the size of the balance sheet. This decline likely reflects the positive, albeit weak, correlation between size and ROE, i.e. larger banks have higher ROE, and vice versa, which explains the ameliorating effect that balance sheet size has on ROE. Similarly, we also note that the response of the ROE to the intensity of use further modestly declines when we control for the investment banks' domicile. This modest decline likely reflects the stronger profitability of US banks vs. their foreign peers. All in all, the regression results shown in Table 6 suggest that the more popular the valuation technique, the lower the banks' relative performance. 
As a robustness check, we also substitute ROE with ROA as an alternative measure of banks' performance. The results remain unchanged as can be seen in Table 7, i.e.: the intensity of use and the banks' profitability exhibit a negative cross-section correlation.

Table 7: Robustness Check - Intensity of Use of Valuation

Techniques and ROA

\begin{tabular}{|c|c|c|c|c|}
\hline $\begin{array}{l}\text { Dependent } \\
\text { variable: ROA }\end{array}$ & (1) & (2) & (3) & (4) \\
\hline Intensity & $\begin{array}{l}-0.046 * * * \\
(0.021)\end{array}$ & $\begin{array}{l}-0.0456^{* * * *} \\
(0.005)\end{array}$ & $\begin{array}{l}-0.0456 * * * \\
(0.005) \\
18 \mathrm{e}-03 * * *\end{array}$ & $\begin{array}{l}-0.0456 * * * \\
(0.005)\end{array}$ \\
\hline Size & & $\begin{array}{l}11 \mathrm{e}-03 * * * \\
(8.2 \mathrm{e}-6)\end{array}$ & $(8.9 \mathrm{e}-6)$ & $\begin{array}{l}15 \mathrm{e}-03 * * * \\
(9.3 \mathrm{e}-6)\end{array}$ \\
\hline U.S. domicile & & & $\begin{array}{l}3.54 * * * \\
(0.004)\end{array}$ & $\begin{array}{l}1.68 * \\
(0.004)\end{array}$ \\
\hline GDP per Capita & & & $\begin{array}{l}3.78 \\
(3.01)\end{array}$ & $\begin{array}{l}23 \mathrm{e}-05^{*} \\
(0.231)\end{array}$ \\
\hline Constant & $\begin{array}{l}2.78 \\
(1.91)\end{array}$ & $\begin{array}{l}3.51 \\
(2.37)\end{array}$ & & $\begin{array}{l}2.51 \\
(4.48)\end{array}$ \\
\hline No. Obs. & 31 & 31 & 31 & 31 \\
\hline Adj. $\mathrm{R}^{2}(\%)$ & 60.08 & 62.51 & 68.34 & 72.31 \\
\hline
\end{tabular}

Turning to the relationship between risk assessment and intensity of use shown in equation (4). Results in table 8 suggest a negative and significant relationship between the intensity of use and the risk assessment. The higher the intensity of use of a valuation technique, the lower is the perceived riskiness of the banks' operating environment and vice versa. From a policy perspective, our findings imply that policymakers now have some tools to monitor banks' risky positions and performance determinants in order to avoid the "too big to fail". For instance, we show that the disclosed range of unobservable inputs is a strong indicator of investment banks' performance.

Table 8: Intensity of Use of Valuation Techniques and Risk Assessment

\begin{tabular}{llll}
$\begin{array}{l}\text { Dependent variable: } \\
\text { Risk assessment }\end{array}$ & $(1)$ & $(2)$ & $(3)$ \\
\hline Intensity & $\begin{array}{l}-0.21^{* *} \\
(0.09)\end{array}$ & $\begin{array}{l}-0.29 * * \\
(0.04)\end{array}$ & $\begin{array}{l}-0.34 * * * \\
(0.01)\end{array}$ \\
& & -0.46 & -0.86 \\
Size & & $(0.38)$ & $(0.93)$ \\
& & & 32.43 \\
U.S. domicile & & & $(3.42)$ \\
& 2.41 & 2.34 & $-21.32 *$ \\
Constant & $(4.68)$ & $(4.31)$ & $(9.31)$ \\
& & & 31 \\
No. Obs. & 31 & 31 & 31 \\
Adj. R ${ }^{2}(\%)$ & 45.9 & 46.8 & 50.2
\end{tabular}

As a final robustness check and in order to account for potential time variation in the relationship between ROE and intensity of use, we run panel regressions of equation (4). The regression results are displayed in table 9. .

Dependent variable: ROE

Table 9: Intensity of Use of Valuation Techniques and ROE Per Year

\begin{tabular}{|c|c|c|c|c|c|c|c|c|}
\hline & \multicolumn{2}{|c|}{ Panel A: $2012((1)-(4))$} & \multicolumn{6}{|c|}{ Panel B: $2013((5)-(8))$} \\
\hline Intensity & $\begin{array}{l}-1.3 e-03 \\
(-1.5 e-03)\end{array}$ & $\begin{array}{l}-1.1 \mathrm{e}-03 \\
(1.4 \mathrm{e}-03)\end{array}$ & $\begin{array}{l}-0.14 \mathrm{e}-03 \\
(1.4 \mathrm{e}-03) \\
5 \mathrm{e}-02 * * * *\end{array}$ & $\begin{array}{l}-0.29 \mathrm{e}-03 \\
(1.4 \mathrm{e}-03)\end{array}$ & $\begin{array}{l}-18 \mathrm{e}-03 * * * \\
(1.9 \mathrm{e}-03)\end{array}$ & $\begin{array}{l}-35 \mathrm{e}-03 * * * * \\
(1.7 \mathrm{e}-03)\end{array}$ & $\begin{array}{l}-50 \mathrm{e}-03 * * * \\
(2.7 \mathrm{e}-03)\end{array}$ & $\begin{array}{l}-58 \mathrm{e}-03 * * * \\
(2.7 \mathrm{e}-03)\end{array}$ \\
\hline Size & & $\begin{array}{l}6 \mathrm{e}-02 \\
(1.76 \mathrm{e}-02)\end{array}$ & $(1.76 \mathrm{e}-02)$ & $\begin{array}{l}4.87 \mathrm{e}-02 * * * \\
(2.39 \mathrm{e}-02)\end{array}$ & & $\begin{array}{l}9 \mathrm{e}-02 * * * \\
(2.55 \mathrm{e}-02)\end{array}$ & $\begin{array}{l}13 \mathrm{e}-02 * * * \\
(3.83 \mathrm{e}-02)\end{array}$ & $\begin{array}{l}19 \mathrm{e}-02 * * * \\
()\end{array}$ \\
\hline $\begin{array}{l}\text { U.S. } \\
\text { domicile }\end{array}$ & & & $\begin{array}{l}-3.00 * * * \\
(0.4511)\end{array}$ & $\begin{array}{l}-3.00 * * * \\
(0.9376)\end{array}$ & & & $\begin{array}{l}0.655^{* * * *} \\
(0.23)\end{array}$ & $\begin{array}{l}0.655^{* * * *} \\
(0.23)\end{array}$ \\
\hline $\begin{array}{l}\text { GDP per } \\
\text { capita }\end{array}$ & & & & $\begin{array}{l}1.25 \mathrm{e}-06^{* * *} \\
(2.27 \mathrm{e}-04)\end{array}$ & & & & $\begin{array}{l}5.17 \mathrm{e}- \\
03^{* * *} \\
(4.91 \mathrm{e}-06)\end{array}$ \\
\hline Constant & $\begin{array}{l}-0.96 \\
(2.67)\end{array}$ & $\begin{array}{l}-0.67 \\
(2.46)\end{array}$ & $\begin{array}{l}-2.33 \\
(2.61)\end{array}$ & $\begin{array}{l}-2.33 \\
(2.65)\end{array}$ & $\begin{array}{l}4.89 \\
(3.92)\end{array}$ & $\begin{array}{l}4.89 \\
(3.65)\end{array}$ & $\begin{array}{l}4.82 \\
(5.50)\end{array}$ & $\begin{array}{l}4,82 \\
(5.64)\end{array}$ \\
\hline \multirow{2}{*}{$\operatorname{Adj} . \mathrm{R}^{2}(\%)$} & \multicolumn{2}{|c|}{ Panel C: 2014 ((8) - (11)) } & \multicolumn{6}{|c|}{ Panel D: $2015((12)-(15))$} \\
\hline & $(8)$ & $(9)$ & $(10)$ & $(11)$ & $(12)$ & $(13)$ & $(14)$ & $(15)$ \\
\hline Intensity & $\begin{array}{l}-1 \mathrm{e}-05^{* * *} \\
(3 \mathrm{e}-06)\end{array}$ & $\begin{array}{l}-1 \mathrm{e}-05^{* *} \\
(4 \mathrm{e}-06)\end{array}$ & $\begin{array}{l}-1 \mathrm{e}-05^{* *} \\
(2.5 \mathrm{e}-06)\end{array}$ & $\begin{array}{l}-5.39 \mathrm{e}-06^{*} \\
(2.61 \mathrm{e}-07)\end{array}$ & $\begin{array}{l}-1.58 \mathrm{e}-06^{* * * *} \\
(1.64 \mathrm{e}-07)\end{array}$ & $\begin{array}{l}-3.03 \mathrm{e}-06^{* * * *} \\
(1.54 \mathrm{e}-07)\end{array}$ & $\begin{array}{l}-4.33 \mathrm{e}-06^{* * * *} \\
(2 \mathrm{e}-07)\end{array}$ & $\begin{array}{l}-4.31 \mathrm{e}-06^{* * * *} \\
(2 \mathrm{e}-07)\end{array}$ \\
\hline Size & & $1.17 \mathrm{e}-03 \mathrm{e}-$ & $1.26 \mathrm{e}-03^{* * *}$ & $1.26 \mathrm{e}-03 * * *$ & & $3.89 \mathrm{e}-06 * *$ & $4.97 \mathrm{e}-06^{* * *}$ & $4.98 \mathrm{e}-06^{* * *}$ \\
\hline
\end{tabular}




\begin{tabular}{|c|c|c|c|c|c|c|c|c|}
\hline & & $\begin{array}{l}03 * * * \\
(1.63 \mathrm{e}-04)\end{array}$ & $(3.51 \mathrm{e}-04)$ & $(3.87 \mathrm{e}-04)$ & & $(5.44 \mathrm{e}-07)$ & $(7.09 \mathrm{e}-07)$ & $(7.17 \mathrm{e}-04)$ \\
\hline \multicolumn{2}{|l|}{$\begin{array}{l}\text { U.S. } \\
\text { domicile }\end{array}$} & & $\begin{array}{l}-10.3 \mathrm{e}-03 \\
(2.1 \mathrm{e}-03)\end{array}$ & \multicolumn{2}{|l|}{$\begin{array}{l}-6.23 e-033 \\
(8.96 e-03)\end{array}$} & & $\begin{array}{l}6.53 \mathrm{e}-03 * * * \\
(1.67 \mathrm{e}-04)\end{array}$ & $\begin{array}{l}6.53 \mathrm{e}-03 * * * \\
(1.69 \mathrm{e}-04)\end{array}$ \\
\hline $\begin{array}{l}\text { GDP per } \\
\text { capita }\end{array}$ & \multicolumn{2}{|c|}{ per } & & \multicolumn{3}{|c|}{$\begin{array}{l}4.74 \mathrm{e}-07 * * * \\
(4.50 \mathrm{e}-08)\end{array}$} & & $\begin{array}{l}3.79 \mathrm{e}-07 * * * \\
(3.6 \mathrm{e}-08)\end{array}$ \\
\hline Constant & $\begin{array}{l}9.6 \mathrm{e}-02 \\
(1.01 \mathrm{e}-02)\end{array}$ & $\begin{array}{l}9.6 e-02 \\
(9.43 e-03)\end{array}$ & $\begin{array}{l}9.3 \mathrm{e}-02 * \\
(5.04 \mathrm{e}-03)\end{array}$ & $\begin{array}{l}9.3 \mathrm{e}-0 * \\
(5.04 \mathrm{e}-03)\end{array}$ & $\begin{array}{l}0.08 * \\
(0.03)\end{array}$ & $\begin{array}{l}0.08 * * \\
(3.1 \mathrm{e}-02)\end{array}$ & $\begin{array}{l}0.09 * * * \\
(4.1 \mathrm{e}-02)\end{array}$ & $\begin{array}{l}0.09 * * * \\
(4.1 \mathrm{e}-02)\end{array}$ \\
\hline No. Obs. & 8 & 8 & 8 & 8 & 7 & 7 & 7 & 7 \\
\hline Adj. $\mathrm{R}^{2}(\%)$ & 37.4 & 41.5 & 40.98 & 43.84 & 53.1 & 53.0 & 51.8 & 52.3 \\
\hline
\end{tabular}

With the exception of 2012, the regression coefficient on the intensity of use is negative and significant during all the subsequent years. Again, the key takeaway is the negative correlation between the valuation techniques' performative process and the ROE. And as show by Table 10 , a similar pattern prevails for ROA.

Table 10: Robustness Check - Intensity of Use of Valuation Technique and ROA, Per Year

Dependent variable: ROA

\begin{tabular}{|c|c|c|c|c|c|c|c|c|}
\hline & \multicolumn{2}{|c|}{ Panel A: $2012((1)-(4))$} & \multicolumn{6}{|c|}{ Panel B: $2013((5)-(6))$} \\
\hline & $(1)$ & (2) & (3) & (4) & (5) & (6) & (7) & (8) \\
\hline Intensity & $\begin{array}{l}-1.86 \mathrm{e}-03 \\
(2 \mathrm{e}-03)\end{array}$ & $\begin{array}{l}-4.01 \mathrm{e}-03 \\
(2 \mathrm{e}-03)\end{array}$ & $\begin{array}{l}-4.01 \mathrm{e}-03 \\
(2 \mathrm{e}-03)\end{array}$ & $-4.01 \mathrm{e}-03(2 \mathrm{e}-03)$ & $\begin{array}{l}-2 \mathrm{e}-03^{* * *} \\
(1.9 \mathrm{e}-05)\end{array}$ & $\begin{array}{l}-3 \mathrm{e}-03 * * * \\
(1.8 \mathrm{e}-05)\end{array}$ & $\begin{array}{l}-3 \mathrm{e}-032 * * * \\
(1.8 \mathrm{e}-05)\end{array}$ & $\begin{array}{l}-2 \mathrm{e}-03 * * * \\
(1.7 \mathrm{e}-05)\end{array}$ \\
\hline Size & & $\begin{array}{l}4.2 \mathrm{e}-02 * * * \\
(6.1 \mathrm{e}-03)\end{array}$ & $\begin{array}{l}4.8 \mathrm{e}-02 * * * \\
(6.1 \mathrm{e}-03)\end{array}$ & $\begin{array}{l}4.2 \mathrm{e}-02 * * * \\
()\end{array}$ & & $\begin{array}{l}1.3 \mathrm{e}-02 * * * \\
(4.3 \mathrm{e}-03)\end{array}$ & $\begin{array}{l}4.3 \mathrm{e}-02 * * * \\
(6.2 \mathrm{e}-03)\end{array}$ & $\begin{array}{l}4.3 \mathrm{e}-02 * * * \\
(5.6 \mathrm{e}-03)\end{array}$ \\
\hline $\begin{array}{l}\text { U.S. } \\
\text { domicile }\end{array}$ & & & $\begin{array}{l}0.016^{* * * *} \\
(1.2 \mathrm{e}-03)\end{array}$ & $\begin{array}{l}0.016 * * * \\
(1.2 \mathrm{e}-03)\end{array}$ & & & $\begin{array}{l}9.3 \mathrm{e}-03 * * * \\
(5 \mathrm{e}-04)\end{array}$ & $\begin{array}{l}9.3 \mathrm{e}-03 * * * \\
(1.4 \mathrm{e}-04)\end{array}$ \\
\hline $\begin{array}{l}\text { GDP per } \\
\text { capita }\end{array}$ & & & & $\begin{array}{l}1.4 \mathrm{e}-08 * * * \\
(3.9 \mathrm{e}-10) \\
-0.009 \\
(0.03)\end{array}$ & & 0.003 & & $\begin{array}{l}3.49 \mathrm{e}-03 * * * \\
(3.14 \mathrm{e}-04)\end{array}$ \\
\hline Constant & $\begin{array}{l}-0.008 \\
(0.036)\end{array}$ & $\begin{array}{l}0.007 \\
(0.031)\end{array}$ & $\begin{array}{l}-0.008 \\
(0.03)\end{array}$ & & $\begin{array}{l}0.003 \\
(0.034)\end{array}$ & $(0.034)$ & $\begin{array}{l}0.003 \\
(0.034)\end{array}$ & $\begin{array}{l}0.003 \\
(0.034)\end{array}$ \\
\hline No. Obs. & 8 & 8 & 8 & 8 & 8 & 8 & 8 & 8 \\
\hline Adj. R ${ }^{2}(\%)$ & 69.32 & 71.34 & 78.25 & 80.28 & 43.2 & 48.3 & 53.5 & 55.8 \\
\hline
\end{tabular}

\begin{tabular}{|c|c|c|c|c|c|c|c|c|}
\hline & \multicolumn{4}{|c|}{ Panel C: $2014((8)-(11))$} & \multicolumn{4}{|c|}{ Panel D: $2015((12)-(15))$} \\
\hline & $(8)$ & $(9)$ & $(10)$ & $(11)$ & $(12)$ & $(13)$ & $(14)$ & $(15)$ \\
\hline Intensity & $\begin{array}{l}-2 \mathrm{e}-05 * * * \\
(2 \mathrm{e}-06)\end{array}$ & $\begin{array}{l}-3 \mathrm{e}-05^{* *} \\
(2 \mathrm{e}-06)\end{array}$ & $\begin{array}{l}-4 \mathrm{e}-05 * * \\
(7 \mathrm{e}-06)\end{array}$ & $\begin{array}{l}-4 \mathrm{e}-05 * \\
(2 \mathrm{e}-06)\end{array}$ & $\begin{array}{l}-1.4 \mathrm{e}-05^{* * *} \\
(1.5 \mathrm{e}-07)\end{array}$ & $\begin{array}{l}-2.7 \mathrm{e}-05^{* * *} \\
(1.4 \mathrm{e}-07)\end{array}$ & $\begin{array}{l}-2.6 \mathrm{e}-05 * * * \\
(3.4 \mathrm{e}-07)\end{array}$ & $\begin{array}{l}2 \mathrm{e}-05 * * * \\
(3.4 \mathrm{e}-07)\end{array}$ \\
\hline Size & & $\begin{array}{l}4.67 \mathrm{e}-03 * * * \\
(3.15 \mathrm{e}-05)\end{array}$ & $\begin{array}{l}4.61 \mathrm{e}-03 * * * \\
(6.55 \mathrm{e}-05)\end{array}$ & $\begin{array}{l}4.61 \mathrm{e}-03 * * * \\
(6.62 \mathrm{e}-05)\end{array}$ & & $\begin{array}{l}3.49 \mathrm{e}-03 * * \\
(4.87 \mathrm{e}-04)\end{array}$ & $\begin{array}{l}8.42 \mathrm{e}-03 * * * \\
(1.2 \mathrm{e}-04)\end{array}$ & $\begin{array}{l}8.44 \mathrm{e}-03 * * * \\
(1.2 \mathrm{e}-04)\end{array}$ \\
\hline $\begin{array}{l}\text { U.S. } \\
\text { domicile }\end{array}$ & & & $\begin{array}{l}8.67 \mathrm{e}-03 \\
(5.32 \mathrm{e}-03)\end{array}$ & $\begin{array}{l}8.55 \mathrm{e}-03 \\
1.1 \mathrm{e}-03)\end{array}$ & & & $\begin{array}{l}2.5 \mathrm{e}-03 * * * \\
(2.84 \mathrm{e}-04)\end{array}$ & $\begin{array}{l}2.5 \mathrm{e}-03 * * * \\
(2.85 \mathrm{e}-04)\end{array}$ \\
\hline $\begin{array}{l}\text { GDP } \\
\text { capita }\end{array}$ & & & & $\begin{array}{l}1.9 \mathrm{e}-06 * * * \\
\left(5.8^{\mathrm{e}}-07\right)\end{array}$ & & & & $\begin{array}{l}3.62 \mathrm{e}-06 * * * \\
(1.06 \mathrm{e}-08)\end{array}$ \\
\hline Constant & $\begin{array}{l}5.27 \mathrm{e}-02 \\
(4 \mathrm{e}-02)\end{array}$ & $\begin{array}{l}5.26 e-02 \\
(3 e-02)\end{array}$ & $\begin{array}{l}5.27 \mathrm{e}-02 * \\
(1.7 \mathrm{e}-02)\end{array}$ & $\begin{array}{l}5.28^{\mathrm{e}}-02 * \\
\left(1.3^{\mathrm{e}}-02\right)\end{array}$ & $\begin{array}{l}5.2 \mathrm{e}-02 * \\
(3 \mathrm{e}-02)\end{array}$ & $\begin{array}{l}5.2 \mathrm{e}-02 * * \\
(2 \mathrm{e}-02)\end{array}$ & $\begin{array}{l}7.1 \mathrm{e}-02 * * * \\
(2 \mathrm{e}-02)\end{array}$ & $\begin{array}{l}5.4 \mathrm{e}-02 * * * \\
(7 \mathrm{e}-03)\end{array}$ \\
\hline No. Obs. & 8 & 8 & 8 & 8 & 7 & 7 & 7 & 7 \\
\hline Adj. R ${ }^{2}(\%)$ & 63.1 & 72.8 & 73.5 & 75.6 & 58.4 & 60.2 & 71.9 & 62.4 \\
\hline
\end{tabular}




\section{Discussion and Conclusions}

We use annual financial statement data available from 2012 to 2015 and extract quantitative and qualitative information with respect to investment banks' valuation techniques. We then rely on the performativity theory to examine the interplay between the popularity of valuation techniques among the banks, the banks' perception of the broader risk environment, and their relative performance. We do so by estimating regression models with fixed effects on unobservable inputs. The regression results reveal two key findings. The first is an inverse relationship between the intensity of use of valuation techniques and the banks' profitability. This inverse relationship suggests that techniques that are more popular adopted by less profitable banks. The second is the inverse relationship between the banks' risk assessment and the intensity of use; i.e.: a wider range of unobservable inputs is typically associated with a less frequently used technique, and vice versa. Taken together, both of these results suggest that the intensity of use mediates the performative process between valuation techniques and ROE.

Granted, the 2016 relaxation of the disclosure requirements clearly puts a constraint on a potential extension of this work to include future annual financial statements. But one way to overcome this constraint is to use survey data. Conducting a well-designed survey among investment banks would allow for a better understanding of the decision-making processes behind valuation techniques, and more specifically, the relationship between the intensity of use, risk assessment, and performance. The use of survey data would therefore allow us to further assess the robustness of our constructs on the intensity of use and the risk assessment.

\section{References}

i. Abrahamson, E., Berkowitz, H. \& Dumez, H., 2016. "A more relevant approach to relevance in management studies: An essay on performativity". Academy of Management Review, 41(2), pp. 367-381.

ii. Andon, P., Baxter, J. \& Chua, W. F., 2007. Accounting change as a relational drifting: A field study experiments with performance measurement. Management Accounting Research, 18(2), pp. 273-308.

iii. Annabi, A. \& Reuben, A. K., 2017. Banks' asset and liability valuation in the new regulatory environment: a game theory perspective. Journal of Banking Regulation., 18(4), pp. 302309.

iv. Austin, J., 1962. How to Do Things with Words. Cambridge, MA: Harvard University Press.

v. Ayres, D., Huang, X. \& Myring, M., 2017. Fair value accounting and analyst forecast accuracy. Advances in Accounting, 37(C), pp. 58-70.

vi. Barron, O. E., Chung, S. G. \& Yong, K. O., 2016. The effect of Statement of Financial Accounting Standards No. 157 Fair Value Measurements on analysts' information environment. Journal of Accounting and Public Policy, 35(4), pp. 395-416.

vii. Baxter, J. \& Chua, W., 2003. Alternative management accounting research - Whence and whither. Accounting, Organizations and Society, 28(2-3), pp. 97-126.

viii. Beatty, A. \& Liao, S., 2014. Financial accounting in the banking industry: A review of the empirical literature. Journal of Accounting and Economics, 58(2), pp. 339-383.

ix. Black, F. \& Scholes, M., 1973. The Pricing of Options and Corporate Liabilities. Journal of Political Economy, May-Jun, 81(3), pp. 637-654.

X. Bürkland, S., Mouritsen, J. \& Loova, R., 2010. Difficulties of translation: making action at a distance work in ERP system implementation. Denmark, Danish National Research Database.

xi. Bushman, R. A., 2014. Thoughts on financial accounting and the banking industry. Journal of accounting and economics, 58(2), pp. 384-395.

xii. Callon, M., 2007. What does it mean to say that economics is performative?. In: D. MacKenzie, F. Muniesa \& L. Siu, eds. Do Economists Make Markets? On the Performativity of Economics. Princeton, NJ: Princeton University Press, pp. 310-357. xiii. Callon, M., Millo, Y. \& Muniesa, F., 2007. An introduction to market devices. Sociological Review, 55(2_suppl), pp. 1-12.

xiv. Callon, M. \& Muniesa, F., 2005. Economic markets as calculative collective devices. Organization Studies, 26(8), pp. 1229-1250.

xv. Chenhall, R., Hall, M. \& Smith , D., 2013. Performance measurement, modes of evaluation and the development of compromising accounts. Accounting, Organizations and Society, 38(4), pp. 268-287.

xvi. Dambrin, C. \& Robson, K., 2011. Tracing performance in the pharmaceutical industry: Ambivalence, opacity and the performativity of flawed measures. Accounting, organizations and Society, 36(7), pp. 428-455.

xvii. Ernst \& Young, 2012. The new fair value disclosures: A snapshot of how public companies adopted the disclosure requirements of ASU 2011-04, U.S.: Ernst \& Young LLP.

xviii. FASB, January 2016. Financial Instruments-Overall: Recognition and Measurement of Financial Assets and Financial Liabilities, Norwalk, CT: Financial Accounting Standards Board.

xix. FASB, May 2011. Amendments to Achieve Common Fair Value Measurement and Disclosure Requirements in U.S. GAAP and IFRSs, Norwalk, CT: Financial Accounting Standards Board.

xx. Gordon, M. J. \& Shapiro, E., 1956. Capital Equipment Analysis: The Required Rate of Profit. Management Science, 3(1), pp. 102-110.

xxi. Gray, S. R. \& Cannelle, A. A., 1997. The role of risk in executive compensation. Journal of Management, 4(23), pp. 517-540.

xxii. Jordan , S. \& Messner, M., 2012. Enabling control and the problem of incomplete performance indicators. Accounting, Organizations and Society, 37(8), pp. 544-564.

xxiii. Landsman, W. R., 2007. Is fair value accounting information relevant and reliable? Evidence from capital market research. Accounting and Business Research, 37(Special Issue: International Accounting Policy Forum), pp. 19-30.

xxiv. MacKenzie, D. A., Muniesa, F. \& Siu, L., 2007. Do Economists Make Markets? On the Performativity of Economics. Princeton, NJ: Princeton University Press.

xxv. MacKenzie, D. \& Millo, Y., 2003. Constructing a market, performing theory: The historical sociology of a financial derivatives exchange. American Journal of Sociology, 109(1), pp. 107-145.

xxvi. Magnan, M., Menini, A. \& Parbonetti, A., 2015. Fair value accounting: Information or confusion for financial markets?. Review of Accounting Studies, 20(1), pp. 559-591.

xxvii. Majercakova, D. \& Skoda, M., 2015. Fair value in financial statements after financial crisis. Journal of Applied Accounting Research, 16(3), pp. 312-332.

xxviii. Modigliani, F. \& Miller, M. H., 1958. The cost of capital, corporation finance and the theory of investment. American Economic Review, June, XLVIII(3), pp. 261-297.

xxix. Morgan Stanley, 2013. Form 10-K, Washington, DC: United States Securities and Exchange Commission.

xxx. Mouritsen, J., 1999. The flexible firm: strategies for subcontractor's management control. Accounting, Organizations and Society, 24(1), pp. 31-55.

xxxi. Palea, V., 2014. Fair value accounting and its usefulness to financial statement users. Journal of Financial reporting and Accounting, 12(2), pp. 102-116.

xxxii. Preda, A., 2006. Socio-technical agency in financial markets: The case of the stock ticker. Social Studies of Science, 36(5), pp. 753-782.

xxxiii. Revellino, S. \& Mouritsen, J., 2015. Accounting as an engine: The performativity of calculative practices and the dynamics of innovation. Management Accounting Review, Volume 28, pp. 31-49. 
xxxiv. Scott, S. \& Orlikowski, W., 2012. Reconfiguring relations of accountability: Materialization of social media. Accounting, Organizations and Society, 37(1), pp. 26-40.

xxxv. Sitkin, S. B. \& Pablo, A. L., 1992. Reconceptualizing the determinants of risk behavior. Academy of Management Review, 17(1), pp. 9-38.

xxxvi. Vosselman, E., 2014. The 'performativity thesis' and its critics: Towards a relational ontology of management accounting. Accounting and Business Research, 44(2), pp. 181-203.

xxxvii. Weber, E. U. \& Milliman, R. A., 1997. Perceived risk attitudes: Relating risk perception to risky choice. Management Science, 2(43), pp. 123-144.

xxxviii. Williams, J. B., 1938; 1997 reprint. The Theory of Investment Value. Wells, VT: Farser Publishing.

xxxix. Wiseman, R. M. \& Gomez-Mejia, L. R., 1998. A behavioral agency model of managerial risk taking. Academy of Management Review, 1(23), pp. 133-153. 